\title{
On the Legitimacy of the Dengist Regime
}

\author{
TORSTEIN HJELLUM
}

Deng's truth-from-facts willingness to discard outmoded dogmas and his black-cats/white-cats readiness to tinker with China's basic economic institutions had led him boldly to venture where no Chinese leader - no leader anywhere in the communist world - had previously dared to go. Early on, Deng decoupled the engine of market competition (good) from the stigma of capitalist exploitation (bad) and threw open China's doors to the outside world, setting in motion a process of accelerated socio-economic development and modernization. . . . Rapid but uneven economic growth, accompanied by a deep erosion of traditional ideological norms and social controls, produced a situation high in raw entrepreneurial energy but low in institutionalized immunity to a wide variety of potential systemic disorders, ranging from rising regional inequality and uncontrolled rural emigration to a nationwide epidemic of crime, corruption, and popular cynicism. All this arguably rendered China more volatile politically than at any time since the late $1940 \mathrm{~s} .{ }^{1}$

\section{Introduction}

Every rapid transformation of a society produces problems of legitimacy for the rulers. In this century the Chinese people have experienced dramatic changes in their society. The market economy has achieved a great dynamic momentum. Capitalism in both crude, simple and complex form is developing. How do people adjust their thinking and their lives to this development? How do the changes influence the relationship between the rulers and the ruled?

No state will survive in the long run if it concentrates its power on suppression and violence. The justifications of power need another basis: it has to build on feelings, morality, on holy doctrines and on some kind of rationality among cultural elites. This thesis has had its supporters among political philosophers and ideologists from Plato, via Machiavelli, up to the political scientists of today. "The strongest man is never strong enough to be always master, unless he trans- 
forms his power into rights and obedience into duty", argued Rousseau, while Hobbes stated that "even the tyrant must sleep". ${ }^{2}$

Political legitimacy means largely the right to rule. It usually comprises three meanings or components. We can call the first of them "self-legitimacy", and this is a set of beliefs that justify to rulers themselves their power and actions. We can name the second "popular legitimacy", which is the acceptance of the ruling groups and their methods by the broad masses. We could name the third "external legitimacy", which is the acceptance of the regime and its ruling groups by other states and by influential segments of public opinion. ${ }^{3}$

The stability of a regime is dependent on the obedience and compliance of the people in relation to the rulers. When people subject themselves to the rulers, the reason may be that they have no alternative; or they may obey because they are accustomed to being obedient; or they obey because they are apathetic or because they calculate subordination as most useful to their interests. The legitimacy of a regime, however, is primarily dependent on the feelings of obedience based on a normative consensus among the people. The legitimacy of a political order may accordingly be defined by the degree of normative acceptance by the populace: Are its procedures perceived as correct? Are the decisions understood as reasonable? And have people the feeling that they are treated fairly? As far as the power of a regime is legitimate, the regime has authority.

We may distinguish between three sources of authority or legitimate power:

- authority based on symbolic authority, based on political mythology;

- authority based on institutionalization of political myths into constitutions and political structures;

- authority that has its sources in political results or the capability of the regime to realize or live up to the commonly accepted political myths.

Consequently, political myths are central aspects in a theory on legitimacy.

Crises of legitimacy are common features of regimes that undergo rapid and deep changes. When custom is not a sufficient reason in itself for the exercise of power, power relations are challenged. This is the situation when traditional power practices are substituted by 
new practices, as I suggest has been the case in China in the 1980s. The reform policies of the Dengists have produced new expectations among the people. Their living conditions, especially the material conditions of life, are expected to be radically improved by a kind of socialism that aims at social equality and solidarity. These expectations are highly contradictory. The regime tries to solve these contradictions by revising old political myths and by constructing new ones.

The hypothesis is that the justification of the Dengist regime of the 1990s has increasingly been dependent on its capacity to produce results that meet the immediate needs of the people - in spite of the ruler's efforts to build its own mythology. This may produce a critical situation for the regime: its legitimacy will be dependent on the economic performance within a world economic system of competitive capitalism while the ideological situation tends towards dissolution and anarchy. The stability of the regime may be increasingly dependent on suppression and violence if the reform policies result in social unrest, as they did in 1989.

\section{A Historical Perspective}

The mythology of the Dengist regime is a mixture of heritages from previous regimes and a result of the regime's own attempts to create political myths. Four historical traditions may be of particular importance: the Confucian tradition from the Celestial Empire; imported Marxism-Leninism from Europe; Western liberalism; and Maoism. When the images of the reforms contradict the political myths from the past, in the form these myths are surviving in people's mind, new justifications are needed. The egalitarianism of Maoism does not easily accord with the Dengist idea that "somebody has to be rich first". Likewise, the collective institutions of Maoism and their ideological justifications do not fit easily into the privatization policies of the Dengists.

One myth of Maoism was that China's backwardness was a result of Western imperialism from the time of the Opium War. This idea justified isolationism. As China has opened up to the outside world, this idea has lost much of its legitimacy. On the other hand, the more open policy may create a need for nationalism as China is becoming an integrated actor on the world markets and a part of an international state system. An emerging great power such as China will 
unavoidably be confronted, both economically and politically, with interests and ambitions of other states and nations. New external enemies to China may create new bases of legitimation to the Beijing regime. They may exploit this possibility in the campaigns of patriotism initiated by the Communist Party of China (CPC). A new nationalism may also be a measure to cope with the influence of Western ideas of democracy among intellectuals in China as "pollution" of "the new imperialism" and the dissolution of old ideas of national identities. ${ }^{4}$

\section{The Dengists' Attempts to Create a Mythology of Its Own}

The reform policy of Dengism was a revitalization of the modernization strategy defeated at the congress of the CPC in 1956. That strategy was developed by Liu Shaoqi and Deng Xiaoping after the failure of The Great Leap Forward. To legitimize this policy, linking it to the past was necessary to justify the discontinuity with the same past. The linkage to the past was necessary because the political myths of Maoism had a stronghold in people's minds and because the leading reform politicians were closely associated with Maoism. That was the reason why the history of the Communist Party had to be rewritten. The new version was presented as a resolution from a plenary meeting of the Central Committee in June $1981 .^{5}$ In this resolution the historical achievements of the party were summed up. According to the resolution, the principles of Marxism-Leninism had been integrated into the concrete practice of the Chinese revolution. This synthesis became the thoughts of Mao. His thoughts became the guideline to unite the Chinese people under the leadership of the Communist Party and to gain victory over feudalism and imperialism. Furthermore, according to the resolution, the victory of the Chinese people inspired people all over the world to fight against imperialism. The next twenty-two years led to great achievements:

- the people became masters of their own country;

- the nation became united;

- the nation had defeated foreign aggression;

- the principle of distribution, "to each according to his work", was put into practice;

- the country was industrialized;

- the agricultural sector was developed after the landlords had 


\section{been suppressed;}

- the fundamental need for food and clothes was met;

- the People's Liberation Army guaranteed peace;

- China, following the principles of proletarian internationalism, became a model for exploited people all over the world. ${ }^{6}$

(The rulers had propagated this story for years and it coincided with experiences of the people.)

Figure 1: A simplified model for the study of the bases of legitimacy of the Dengist regime

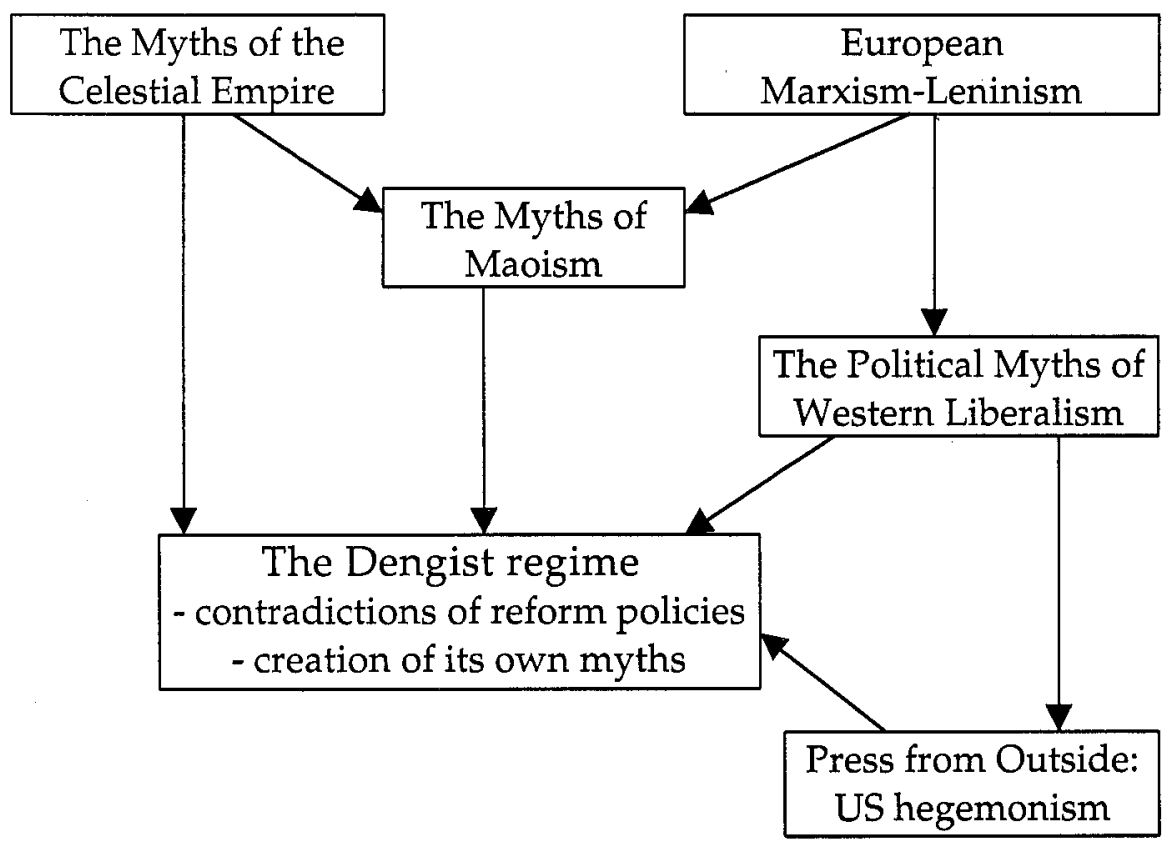

According to the party's resolution, grave errors were committed after 1957: the Cultural Revolution became a backlash for Chinese socialism; the theory of a continued class struggle under socialism had been an error and a deviation from Maoism; there had never existed a "bourgeois headquarter" inside the party, led by Liu Shaoqi and Deng Xiaoping. Most of the participants in the Cultural Revolution had placed great faith in the leadership of Mao Zedong, and Mao was mainly responsible. However, the Cultural Revolution was the failure "of a great proletarian revolutionary". In spite of these failures, important advances had taken place in the ten-year period 1966-76. So far, according to the resolution.

Deng was in 1981 in the same dilemma that Khrushchev had ex- 
perienced after his speech about Stalin in 1956. He was himself jointly responsible for Stalinism, therefore, he had to balance the criticism. Such a balancing policy was also necessary because the masses of the people were not ready to dethrone Mao. He had also to carry out another balancing act. He had allow dissident voices to be heard so as to distance himself from the oppression of the Cultural Revolution. In 1979 he at first welcomed the "democracy wall", but suppressed it subsequently when dissidents asked for a fifth modernization, a reform of the political system. Had the Dengists learned a lesson from the Soviet Union, where dissidents like Solzhenitsyn and Sakharov had assumed the dangerous role of critics of the regime from within the system ${ }^{7}$

The resolution of 1981 explained that because of the short history of socialism, it is understandable that errors were committed. Emancipating China from the influence of feudal political traditions that had lasted for thousands of years was not easy. Among the tasks of the reformers was the need to institutionalize the political system and to change the over-concentration of power. Three years after the power takeover by the reformists, the resolution summed up that 1978 had become "a great turning point in history".

Nevertheless, the legacy from the Maoist past, with its corrections, was not sufficient to legitimize the new regime. The Dengists had to create their own political mythology. The notion of "socialism with Chinese characteristics" was introduced by Deng Xiaoping in his opening address to the twelfth national party congress in 1982:

We must integrate the universal truth of Marxism with the concrete realities of China, blaze a path of our own and build a socialism with Chinese characteristics - that is the basic conclusion we have reached after summing up long historical experience. ${ }^{8}$

Deng said that this party congress was the most important since 1945. The congress that year canonized the thoughts of Mao as the ideological basis of communism in China. Deng wanted to indicate a historical divide, but the creation of the notion "socialism with Chinese characteristics" also had a more pragmatic explanation. The reform policies initiated since 1978 had met with objections. Deng argued in favour of reforms that could be accepted by as many Chinese people as possible: by elite people and by the population at large. Two years after the congress, twenty-one of Deng's speeches were published under the title Build Socialism with Chinese Characteristics. The party congress in 
1992 gave this notion status as a theory. In his report to the congress, secretary general Jiang Zemin gave an interpretation of the concept. To build socialism with Chinese characteristics had been the aim throughout all fourteen years of reform, he told the congress. Mao had led the new democratic revolution. Now a new revolution had been set into motion. The congress summed up the characteristics of this "Chinese socialism" in ten points:

1) China follows its own path, seeks truth from facts and builds its socialism according to its specific experiences.

2) China is in the initial stage of socialism, an era that will last more than a hundred years.

3) The development of the productive forces (the technology) is the most important task.

4) The object of the structural economic reforms is to develop a "socialist market economy".

5) China has to open up to the outside world to guarantee peace and take advantages of the experiences of others. This would also include the development of capitalism.

6) "The four cardinal principles" are the foundation: the socialist road; the dictatorship of the proletariat; the leadership of the Communist Party; and Marxism-Leninism-Mao Zedong's Thoughts.

7) Socialism does not mean poverty and social polarization. However, somebody has to be rich first if China is to realize the goal of prosperity for all.

8) The Communist Party has the leading role and the army, led by the party, should defend the reforms.

9) "One country, two systems", a peaceful unification of Hong Kong, Macao and Taiwan with mainland China: the mainland will work for socialism while capitalism will survive in the three areas.

10) To seek truth from facts means pragmatic adjustment of the theory.

These ten points introduced a new notion: "socialist market economy". 
Table 1: The legitimizing ideas of Dengism compared to political myths of past regimes and Western liberalism

\begin{tabular}{|c|c|c|c|c|}
\hline Concept of & $\begin{array}{l}\text { Myths of } \\
\text { imperial rule }\end{array}$ & $\begin{array}{l}\text { Myths of } \\
\text { Maoism }\end{array}$ & $\begin{array}{l}\text { Myths of } \\
\text { Dengism }\end{array}$ & $\begin{array}{l}\text { Myths of } \\
\text { liberalism }\end{array}$ \\
\hline Ruler(s) & $\begin{array}{l}\text { Son of Heaven } \\
\text { rules by virtues } \\
\text { and rites }\end{array}$ & $\begin{array}{l}\text { Mao, a great } \\
\text { revolutionary, } \\
\text { teacher of the } \\
\text { people, founder of } \\
\text { Chinese socialism }\end{array}$ & $\begin{array}{l}\text { Contradictory: } \\
\text { Deng the } \\
\text { paramount } \\
\text { leader; veterans } \\
\text { against experts }\end{array}$ & $\begin{array}{l}\text { Sovereignty of the } \\
\text { people through } \\
\text { democratic elections }\end{array}$ \\
\hline Democracy & $\begin{array}{l}\text { Common people } \\
\text { are subjects, not } \\
\text { citizens, but with } \\
\text { the right to rebel } \\
\text { against bad rulers }\end{array}$ & $\begin{array}{l}\text { Workers and } \\
\text { peasants are the } \\
\text { ruling classes } \\
\text { through the CPC; } \\
\text { mass line; mass } \\
\text { campaigns }\end{array}$ & $\begin{array}{l}\text { The leading role } \\
\text { of CPC; Western } \\
\text { liberalism means } \\
\text { spiritual Pollution }\end{array}$ & $\begin{array}{l}\text { Political democracy } \\
\text { through free } \\
\text { elections; common } \\
\text { people are citizens }\end{array}$ \\
\hline Class & Scholarly elitism & Class society & $\begin{array}{l}\text { "somebody has to } \\
\text { be rich first"; } \\
\text { "socialist market } \\
\text { economy" }\end{array}$ & $\begin{array}{l}\text { Pluralism of com- } \\
\text { petitive interests }\end{array}$ \\
\hline Individual & $\begin{array}{l}\text { Member of } \\
\text { patriarchal social } \\
\text { systems }\end{array}$ & $\begin{array}{l}\text { Egalitarianism, } \\
\text { ruling elites of } \\
\text { party cadres }\end{array}$ & $\begin{array}{l}\text { CPC in the lead, } \\
\text { new authoritaria- } \\
\text { nism; human } \\
\text { rights a Western } \\
\text { concept }\end{array}$ & $\begin{array}{l}\text { Everybody is sinful } \\
\text { facing God; human } \\
\text { rights; individual- } \\
\text { ism }\end{array}$ \\
\hline China & $\begin{array}{l}\text { All under } \\
\text { Heaven", The } \\
\text { Kingdom in the } \\
\text { Middle }\end{array}$ & $\begin{array}{l}\text { Leadership in } \\
\text { worldwide anti- } \\
\text { imperialism }\end{array}$ & $\begin{array}{l}\text { Patriotism; a } \\
\text { strong and united } \\
\text { China led from } \\
\text { Beijing }\end{array}$ & $\begin{array}{l}\text { Should be civilized } \\
\text { and similar to We- } \\
\text { stern democracies }\end{array}$ \\
\hline $\begin{array}{l}\text { Institutio- } \\
\text { nalism }\end{array}$ & $\begin{array}{l}\text { The Emperor } \\
\text { religious and } \\
\text { worldly authority; } \\
\text { rule by man }\end{array}$ & $\begin{array}{l}\text { Dictatorship of the } \\
\text { proletariat } \\
\text { through the one- } \\
\text { party state }\end{array}$ & $\begin{array}{l}\text { Dictatorship of } \\
\text { the proletariat } \\
\text { through the one- } \\
\text { party state; lega- } \\
\text { lization (rule by } \\
\text { law) }\end{array}$ & $\begin{array}{l}\text { Rule by law based } \\
\text { on human rights }\end{array}$ \\
\hline Conflict & Harmony & $\begin{array}{l}\text { Class struggle } \\
\text { (Mao, On Contra- } \\
\text { diction) }\end{array}$ & $\begin{array}{l}\text { Dictatorial har- } \\
\text { mony; priority to } \\
\text { stability and } \\
\text { order } \\
\end{array}$ & $\begin{array}{l}\text { Competitive par- } \\
\text { liamentarianism }\end{array}$ \\
\hline Ideology & $\begin{array}{l}\text { Mandate of } \\
\text { Heaven; Confu- } \\
\text { cianism }\end{array}$ & $\begin{array}{l}\text { Marxism-Lenin- } \\
\text { ism-Mao Ze- } \\
\text { dong's Thoughts }\end{array}$ & $\begin{array}{l}\text { Socialism with } \\
\text { Chinese charac- } \\
\text { teristics }\end{array}$ & $\begin{array}{l}\text { Ideological plural- } \\
\text { ism }\end{array}$ \\
\hline
\end{tabular}

In 1980 Deng had initiated reforms of party and state institutions. He argued that the main obstacles to the reform policies were bureaucracy, concentration of power, patriarchal methods, lifelong tenure in leading positions, and different kinds of privileges. ${ }^{9}$ To attack such tendencies the party organized a "disciplinary committee". They called on veteran cadres to give up their positions and move to the newly formed "advisory committee". A programme was set up to 
establish a new third echelon of leaders. The results seem, however, to be meagre, and the veteran cadres continued to play an important role in the state and party leadership. Instead of institutionalization of procedures, a strengthening of traditional and personal-based linkages seems to have been the outcome.

Confucianism was deeply imbedded in old traditions and institutions. Marxism drew its strength from a consistent critique of the past and a bright vision of the future. Marxism had been systematically propagated by the totalitarian state. Both the Celestial Empire and Maoism developed powerful mythologies. Compared to Confucianism and Maoism, the mythology of Dengism appeared inconsistent and pragmatic and only occasionally propagated by a weakening party machine. The party's ability to convince the people was doubtful.

\section{Popular Legitimacy Tested by a Survey in Larger Chinese Cities}

The suggestion that the Dengist "self-legitimacy" is weak - and maybe weakening - is not easy to prove. The "popular legitimacy", the acceptance of the ruling groups and their methods by the broad masses, might prove easier to study simply by asking the people: Which economic, social and political needs and wishes do people have and how do they expect the government to behave in relation to these expectations? To what degree are the people satisfied with the efficiency and efficacy of their government?

This method has also been discovered by the regime itself. Since the middle of the 1980s, the Chinese state and the Communist Party have initiated surveys among the masses to check out how people respond to the reform policies. ${ }^{10} \mathrm{I}$ shall present below some data from a survey in 1993 of 2,285 persons in thirty-nine large cities in China. ${ }^{11}$

How do urban Chinese view the social and political situation in the country? The answers to a set of questions relating to this reflect a population that is strongly critical and dissatisfied.

- $60 \%$ say that their government is corrupt;

- $62 \%$ say that the government's efficiency is low;

- $63 \%$ feel a lack of openness in government; that there is insufficient access to information about what is going on at the top level 
of politics;

- $47 \%$ feel that law and order in society are deteriorating and that there is a growing feeling of insecurity;

- $48 \%$ feel that life chances and opportunities for personal development are unfairly distributed;

- $53 \%$ say that there is too much lawlessness;

- $58 \%$ consider that there is a tendency to moral decay;

- $32 \%$ feel that the political situation is unstable.

If we combine the answers to these eight questions, we find the following correlations: persons who feel that the government is corrupt, also think that it is ineffective $(r=0.59)^{12}$; the people who feel that the government is ineffective also think that there is a situation of moral decay in the society $(\mathrm{r}=0.49)$, and so on.

Table 2: Correlation between opinions of government and social conditions

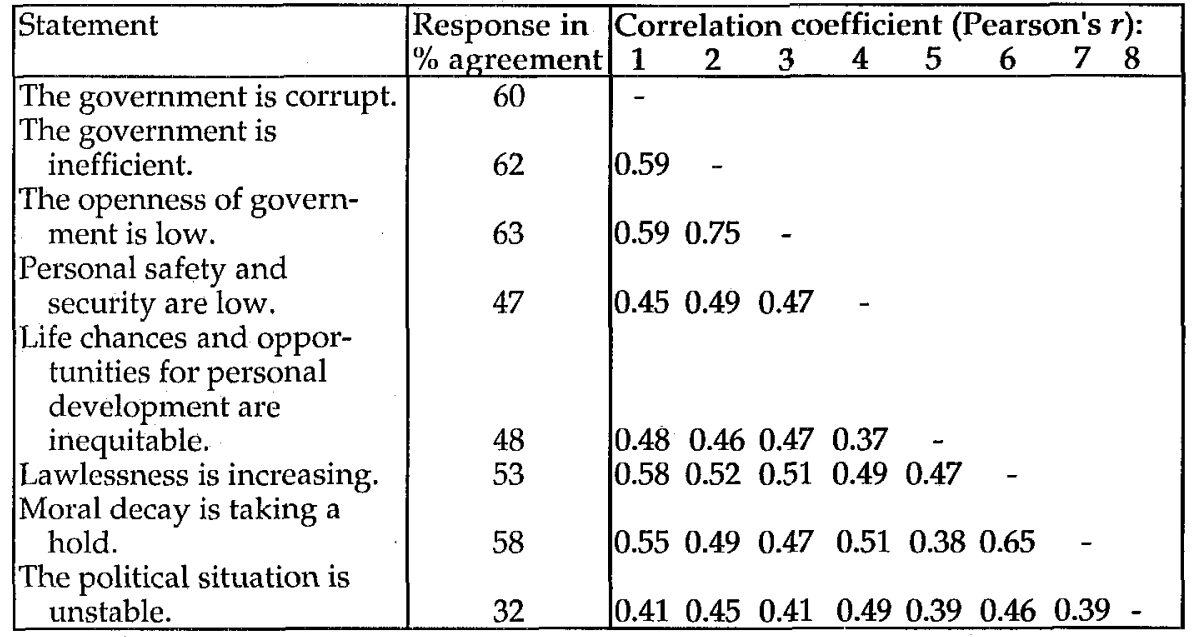

The survey analyses indicate a hard core of critical people comprising about 15 per cent of the urban population. These people are critical to the regime on all eight levels. One third of them have a university education - a high ratio compared with the rest of the surveyed sample. Workers with low education are, for instance, less critical to the regime.

If we break down the answers to the eight questions by party membership, we find that members of the CPC are as critical as nonmembers. It means that people that we would suppose to be the most loyal to the regime are not necessarily so. Dissatisfaction with 
the social and political situation thus represents a potential for unrest and conflict within the ruling party.

Table 3: Opinions on the government and social conditions according to political status (Response in \%)

\begin{tabular}{|l|c|c|}
\hline \multicolumn{1}{|c|}{ Statement } & $\begin{array}{c}\text { Member of CPC } \\
(\mathrm{N}=541=100 \%)\end{array}$ & $\begin{array}{c}\text { Not a member of CPC } \\
(\mathrm{N}=1553=100 \%)\end{array}$ \\
\hline $\begin{array}{l}\text { The government is } \\
\text { corrupt }\end{array}$ & 62 & 59 \\
honest and clean & 8 & 10 \\
\hline $\begin{array}{l}\text { Government efficiency is } \\
\text { low }\end{array}$ & 64 & 62 \\
high & 7 & 10 \\
\hline $\begin{array}{l}\text { Social morality is } \\
\text { degenerating } \\
\text { healthy }\end{array}$ & 63 & 58 \\
\hline Life chances and opportunities & 11 & 13 \\
for personal development are & & \\
inequitable & 45 & 49 \\
equitable & 10 & 14 \\
\hline The openness of government is & & 62 \\
low & 65 & 10 \\
high & 8 & \\
\hline
\end{tabular}

In our in-depth interviews, we also met people who were very critical of the regime. Did they see any alternative to the ruling party? Their answers were negative: "China needs stability. We have no alternative to the one-party state. No alternative is possible in China today."

Most Chinese are concerned about the international situation and their country's reputation abroad. More than 60 per cent of the interviewees felt that the reform policy after 1978 had improved China's international position. In an in-depth interview, a young female student expressed satisfaction with China's growing international prestige, a development that she hoped would give China back the superpower position it had enjoyed before the invasion of Western colonial powers. Campaigns of patriotism initiated by the government may thus have a potential to strengthen the legitimacy of the regime.

The urban Chinese have ideas of what "a good life" should be, but they express a widespread dissatisfaction with their actual living conditions. On the other hand, they are very satisfied with the im- 
provements in their material living conditions due to the reform policies. They are optimistic and have great hopes for future reforms. The contradiction between real life and great expectations for the future represents a potential for social unrest if the reform policies were to experience grave set-backs. ${ }^{13}$

Table 4a: Levels of satisfaction with living conditions (Response in \%)

\begin{tabular}{|l|c|c|c|c|}
\hline Social area & $\begin{array}{c}\text { Very } \\
\text { satisfied }\end{array}$ & Satisfied & $\begin{array}{c}\text { Not } \\
\text { Satisfied }\end{array}$ & $\begin{array}{c}\text { Very } \\
\text { Dissatisfied }\end{array}$ \\
\hline Income & 3 & 15 & 30 & 21 \\
\hline Housing & 4 & 21 & 24 & 21 \\
\hline Health care & 4 & 16 & 28 & 22 \\
\hline Transportation & 4 & 18 & 29 & 16 \\
\hline
\end{tabular}

In table 4b, respondents were asked: "Do you agree with the following statements as compared with your own experiences?"

Table $4 b$ : Statements about the quality of life (Response in \%)

\begin{tabular}{|l|c|c|c|c|}
\hline Statement & Quite true & True & False & Quite false \\
\hline TV programmes are meaningless. & 13 & 37 & 21 & 3 \\
\hline $\begin{array}{l}\text { The quality of education in school is } \\
\text { too poor. }\end{array}$ & 12 & 35 & 29 & 6 \\
\hline $\begin{array}{l}\text { No recreational places can be found } \\
\text { to relieve boredom. }\end{array}$ & 15 & 36 & 5 & 4 \\
\hline $\begin{array}{l}\text { The wish to travel to other parts of } \\
\text { the country is hardly realizable. }\end{array}$ & 29 & 39 & 9 & 3 \\
\hline $\begin{array}{l}\text { Sometimes, I really find it meaning- } \\
\text { less to live. }\end{array}$ & 8 & 27 & 31 & 11 \\
\hline
\end{tabular}

An overwhelming majority ( 80 per cent) of the interviewees reported that their own living conditions had improved during the last fifteen years. They felt that the reform policy had been a great success; the agricultural reforms were mentioned as the most successful. The survey also indicated that 40 per cent felt that they enjoyed more political freedom. However, 70 per cent said that they had no influence at all in politics, neither at the central nor at the local level. A total of 55 per cent felt that "the cultural life" had become richer. As for the future of the reform policy, two out of three expressed optimism.

On the other hand, the negative developments in the society which they reported were also ascribed to the reform policies. Two out of three felt that the people's mentality had changed for the worse. The Chinese had become greedy; everything had become an 
object of buying and selling. If one wanted to obtain something, one had humbly to ask favours of others, they reported. These results leave us with the impression that the traditional system of guanxi $i^{14}$ is recovering - and that many dislike it.

The survey also tells us that the family as a social nucleus plays an important role in urban Chinese society. Family relations are reported as harmonious. This is true for the relations between husband and wife, and between generations within the family. Two out of three respondents reported very little quarrelling between family members: husband and wife care about each other, they are faithful to each other and they have no intention of divorce. Two of three report that family members always help one another when there are problems. They have a strong feeling of responsibility towards one another. When the interviewees were asked about what they would do if they were dissatisfied with a specific reform, 65 per cent said that they would first discuss the issue within their family. Among different options of a good life, a good family life was chosen as the most important. The priority is given to care between spouses (70 per cent), mutual responsibility within the family ( 53 per cent), good relations between generations ( 35 per cent) and the family as an arena of problem solving ( 31 per cent).

In an authoritarian political culture, the masses are subjects of rule. No political myth tells them that they should be participants in politics. On the contrary, prevailing myths tell them that they are politically incompetent, and if they engage in politics, they are suppressed. Maoism in China invited people to participate in politics, on the premises of the communists, thus a kind of participating culture developed under Mao. How do urban people today look upon themselves, as subjects or participants? Some questions in the survey relate to this issue.

Table 5: "Somebody has to be the leader of our country and make decisions on behalf of the rest of us."

\begin{tabular}{|l|c|c|}
\hline What is your opinion on the following statements? & Agree & Disagree \\
\hline $\begin{array}{l}\text { "Who rules is not a question that the ordinary citizen } \\
\text { should care about." }\end{array}$ & 29 & 52 \\
\hline $\begin{array}{l}\text { "The main task of ordinary people is to follow the deci- } \\
\text { sions of the government in the best possible manner." }\end{array}$ & 40 & 43 \\
\hline $\begin{array}{l}\text { "Citizens should openly express their disapproval of } \\
\text { bad leaders." }\end{array}$ & 76 & 8 \\
\hline
\end{tabular}


One third of the respondents think that the rulers should rule and that they themselves should obey, which is a typical "subject" perspective. On the other hand, they also think that citizens should protest against bad leaders. This may be interpreted in line with the Confucian tradition: people have a right to rebel against a ruler who has lost his mandate, and against a ruler whose politics do not satisfy the people's needs. In the perspective of legitimacy, the Dengist regime has a source of support among a traditionally oriented public as long as its reform policies satisfy their wishes for improved material living conditions.

We may suggest that there exist segments of the population with a participative orientation. Among such segments, the system has legitimacy if it has decision-making institutions in which they can participate. According to the survey, 23 per cent of the urban population are organized in the Youth League of CPC, 24 per cent are members of CPC, and 2 per cent are members of a democratic party. ${ }^{15}$ Because people with higher education are over-represented in the survey population, these figures may be too high. Anyway, they give us an opportunity to compare CPC members with the rest of the population.

The survey tells us that half of the members of CPC have been recruited since 1982, that is during the era of reform. Membership is considered attractive: 44 per cent of the non-members in the survey population want to be members. Why is it so? Is the reason that membership in CPC opens opportunities of political participation in decision-making?

Table 6: Membership of the Communist Party of China (Response in \%)

\begin{tabular}{|l|c|}
\hline Statement & Response \\
\hline I am a member of the Youth League. & 23 \\
I am a member of CPC. & 24 \\
I am a member of a democratic party. & 2 \\
\hline If you are a member of CPC, when did you join? & 50 \\
- before 1982 & 37 \\
- 1982-89 & 12 \\
- 1990-93 & \\
\hline If you are not a member of CPC, do you want & \\
to be a member? & 44 \\
- yes & 51 \\
\hline
\end{tabular}


From the in-depth interviews we carried out in Beijing in 1993, it was evident that members in the Youth League did not play any role in decision-making. Members did not report political activity. The same goes for CPC membership, according to the in-depth interviews. However, membership of the party was of importance, according to interviewees, because it is an asset on the job market and for your career in a political and economic system where party members hold all important positions.

The interviewees were asked to evaluate their own influence on political decisions. Seven out of ten felt that they had no influence at all on the national and local government. Only 1 per cent felt that they had a great amount of influence. When CPC members and nonmembers are compared, we find that there is a slight difference between the two groups. The CPC members are more inclined to report influence. The main picture is, however, a feeling of powerlessness even among CPC members.

Table 7: "How much influence do you think you have on the decisions made by national/local government" (Response in \%)

\begin{tabular}{|l|c|c|}
\hline Degree of influence & $\begin{array}{c}\text { National } \\
\text { government level }\end{array}$ & $\begin{array}{c}\text { Local } \\
\text { government level }\end{array}$ \\
\hline Great amount & 1 & 1 \\
Reasonable amount & 5 & 2 \\
So-so & 10 & 11 \\
Little & 3 & 2 \\
Very little & 11 & 12 \\
None at all & 68 & 71 \\
\hline
\end{tabular}

To be a member of CPC may still be regarded as an honorary position. In addition it may represent a widening of one's network. To have guanxi within the party may be of importance. In relation to participation in decision-making processes, however, party membership does not seem to work if ordinary people want to have a say in politics. How then would people express their views?

Most of the interviewees would choose a private solution. They would complain to family and friends, a solution they regard as not very effective. Some would also report their views to relevant offices. They were not asked whether they had ever done so. One third would do nothing. 
Table 8: "How much influence do you think you have on decisions made by: (a) your national government; (b) your local government; (c) voting?" (Response in \%)

\begin{tabular}{|l|c|c|c|c|c|c|}
\hline & \multicolumn{2}{|c|}{$\begin{array}{c}\text { (a) Your national } \\
\text { government }\end{array}$} & \multicolumn{2}{c|}{$\begin{array}{c}\text { b) Your local } \\
\text { government }\end{array}$} & \multicolumn{2}{c|}{ (c) By voting } \\
\hline & $\begin{array}{c}\text { CPC } \\
\text { members }\end{array}$ & Others & $\begin{array}{c}\text { CPC } \\
\text { members }\end{array}$ & Others & $\begin{array}{c}\text { CPC } \\
\text { members }\end{array}$ & Others \\
\hline Much & 8 & 6 & 3 & 3 & 5 & 5 \\
\hline So-so & 12 & 10 & 13 & 10 & 12 & 9 \\
\hline Little & 19 & 12 & 19 & 12 & 28 & 18 \\
\hline None at all & 61 & 70 & 65 & 73 & 55 & 67 \\
\hline
\end{tabular}

Table 9: "If you are dissatisfied with a reform policy and how it is implemented, what would you do?" (Response in \%)

\begin{tabular}{|l|c|}
\hline Action & Response \\
\hline Complain to family and friends. & 65 \\
\hline $\begin{array}{l}\text { Report to the government department with help of friends } \\
\text { or guanxi. }\end{array}$ & 21 \\
\hline Report to departments concerned and express your views. & 30 \\
\hline Write to the newspaper and express your views. & 25 \\
\hline Report to the people's delegates in your unit. & 27 \\
\hline $\begin{array}{l}\text { Visit the official departments, send petitions or protest by } \\
\text { demonstrations. }\end{array}$ & 8 \\
\hline Undertake civil disobedience. & 11 \\
\hline Do nothing. & 27 \\
\hline
\end{tabular}

Dissatisfaction with the lack of rights to participate in public life, like freedom of speech, organization and voting rights, is widespread among the urban population. Between 40 and 50 per cent had no opinion and were indifferent. These high numbers support the hypothesis that many Chinese still do not relate their thinking to civil human rights: 30 per cent were not satisfied with their right to personal expression; 25 per cent were satisfied. An interpretation may be that Chinese people now have more freedom to express their views in private than before and more freedom from control of their daily life. Such a conclusion received support in the in-depth interviews. On the other hand, the widespread criticism of lack of liberal and democratic rights represents a serious problem for the legitimation of a regime that has been very restrictive regarding political reforms. 
Table 10: Opinions about civil rights (Response in.\%)

\begin{tabular}{|l|c|c|c|}
\hline Civil rights & Satisfied & No opinion & Dissatisfied \\
\hline $\begin{array}{l}\text { The right to know about the government } \\
\text { work and function }\end{array}$ & 13 & 40 & 44 \\
\hline $\begin{array}{l}\text { The right to express personal views } \\
\text { openly and freely }\end{array}$ & 25 & 44 & 30 \\
\hline $\begin{array}{l}\text { The freedom of the press and of } \\
\text { publication }\end{array}$ & 8 & 43 & 46 \\
\hline $\begin{array}{l}\text { The right to present suggestions and } \\
\text { proposals to the leaders of your unit }\end{array}$ & 14 & 50 & 34 \\
\hline The right to criticize government & 14 & 55 & 28 \\
\hline The right to vote & 11 & 44 & 43 \\
\hline $\begin{array}{l}\text { The right to participate in all kinds of } \\
\text { organizations and groups }\end{array}$ & 10 & 46 & 42 \\
\hline The right to assemble and demonstrate & 15 & 57 & 24 \\
\hline
\end{tabular}

Analyses of correlation show that there is a group of people who are dissatisfied over the whole range of questions on political rights. They can be interpreted to be antagonists of the whole political system.

Table 11: Correlation between opinions on rights

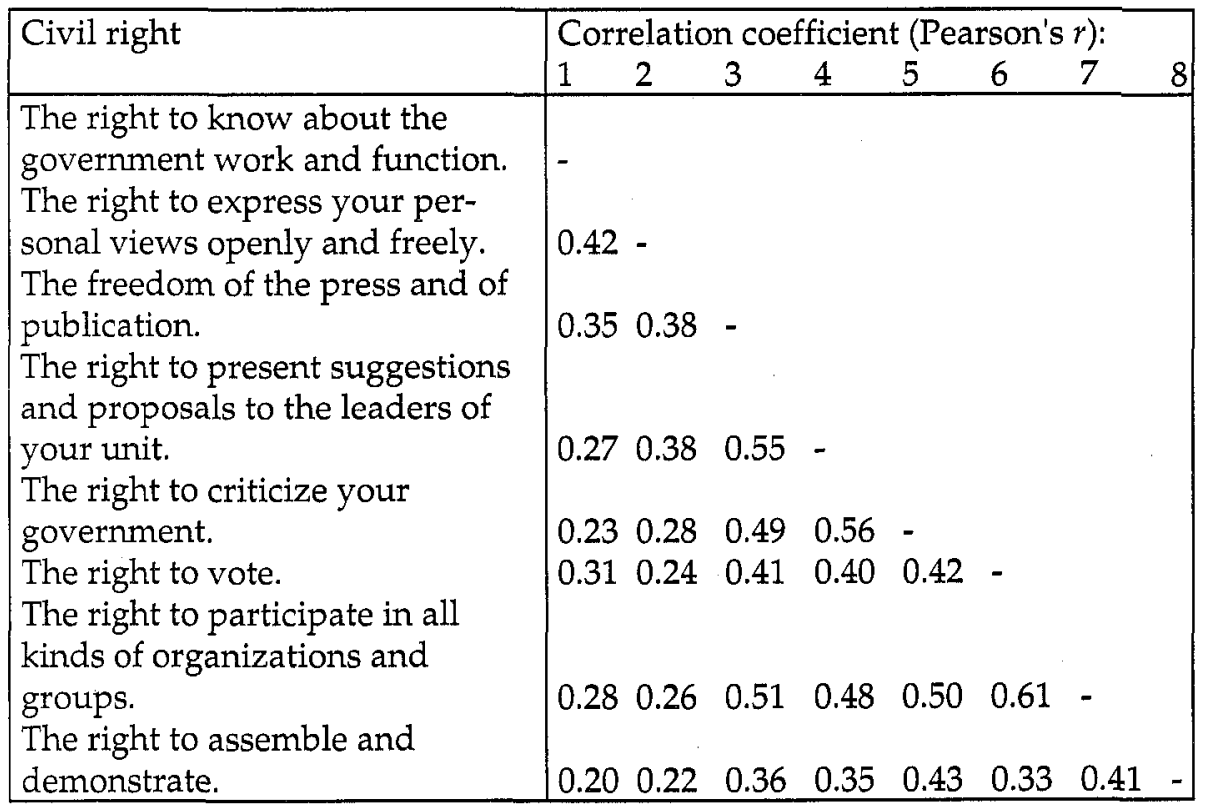

Who are these potential critics of the system? Who are the indifferent? And who are the people that are explicitly positive to the regime? An analysis of the survey data gives us these estimates: about 20 per cent of the interviewees are consolidated as critics of the lack 
of democratic political rights; about one-third are indifferent; and a small minority (less than 10 per cent) are satisfied. About 40 per cent have an unclear and partly contradictory profile in relation to these variables of rights.

If we group these four categories according to age, sex and political affiliation, we find no statistically significant differences. We find party members evenly distributed in the three groups. Of the "system-critical" category, 36 per cent had a university education: this is a much higher percentage than in the other categories. The critical are also mainly occupied in public areas, like education, health care and cultural work.

\section{Summing Up}

Has the Dengist regime of the 1990s legitimacy? The question is difficult to answer, for several reasons:

- The question is formulated in general and an answer will unavoidably cover variations according to region, social groups or classes, generations, etc. An answer will under all circumstances represent a rough simplification.

- There is a lack of relevant data; our data are narrow in scope and are not representative for the population as a whole.

- To measure the strength of myths in a population requires more probing methods than a structured mass survey can accomodate.

In spite of problems like this, the question of legitimacy has always been of core interest to political scientists (and to all political regimes). On the basis of the survey we can at least draw a number of conclusions:

- The Chinese have expectations vis-à-vis their rulers based on political myths of the past. They expect a ruler to behave according to some conventional virtues. Therefore, they are very critical of the corrupt character of the Dengist regime: it is not effective in its performance and it does not handle the citizens on an egalitarian base - an idea propagated by the past Maoist regime.

- The Chinese political culture is predominantly a subject political culture. However, the Chinese do have expectations of their rulers. Measured by these expectations, the majority seem to have a mainly negative attitude to the regime, with one very important exception: the reform policies have benefited most Chinese and 
mainly negative attitude to the regime, with one very important exception: the reform policies have benefited most Chinese and improved their life materially. Most Chinese are optimistic. They think that their lives will improve thanks to the further success of the reform policy.

- On the other hand, the regime is blamed because of the unavoidable (?) problems which "modernization" produces: a dissolution of social order and decay of social morality.

- Instead of an institutionalization of politics, and the development of an "organizational mode of association" as in Western societies, the traditional "differential mode of association"16 where guanxi is the key to achieve one's interests, is strengthening. The ordinary Chinese may not be satisfied with such a development. The role of the family may be strengthened after the set-back of the collective experiments of Maoism.

- Most urban Chinese do not have a participatory attitude to a political system based on ideas of individual rights and duties. Only a small minority are demanding political rights associated with Western democracies. This minority have no political alternative and are not ready to start building a political alternative to the existing regime. On the other hand; the lack of access to the decision-making processes combined with a possibly growing dissatisfaction with the regime may constitute a destabilizing factor.

- In the eyes of ordinary Chinese, the Dengist regime may have lost much of its "Mandate of Heaven". Many of them may think they have a right to rebel; however, their actions will be limited by the wish to avoid social turmoil or anarchy in the society. The oneparty state will continue as a virtue of necessity. ${ }^{17}$

- The effects of the regime's effort to construct its own political myths ("Socialism with Chinese characteristics") are not easy to measure. Perhaps its ambitions are limited to appeasing frustrations among older generations of Chinese over vanishing utopian ideas of communism. On the other hand, national pride may be strengthened and nourished by the rulers, via China's economic and political growth as a big power. ${ }^{18}$

- Among ordinary members, party membership does not seem to function as an opportunity to participation or as a channel of influence. Furthermore, membership does not necessarily equate 
with loyalty to the regime. Party members are also very critical of the efficiency and efficacy of the system.

My hypothesis from the outset was that the justification of the Dengist regime will be increasingly dependent on its capacity to meet the immediate needs of the people, and that the regime's own efforts to construct its own mythology will be limited. I feel that the data from the survey in 1993 support this hypothesis. The "popular legitimacy" of the regime seems causal. If so, the regime is encumbered with a serious weakness.

What may happen with China in such a situation? I am inclined to make Adam Przeworski's words my own:

... imagine that the authoritarian regime suffers a loss of legitimacy but no alternative regime is accessible, that is, no coherent alternative is politically organized. What would then happen? This is clearly a question open to and inviting an empirical investigation, but I do have a guess: nothing much. ${ }^{19}$

Torstein Hjellum is Associate Professor at the Department of Comparative Politics at University of Bergen, Norway. The article is a revised version of a paper presented at the Third Conference of the "State and Society in East Asia" Network, 27-29 September 1996 in Copenhagen.

\section{NOTES}

1 Richard Baum, Burying Mao (Princeton: Princeton University Press, 1994), pp. 391, 392.

2 Legitimacy is a classical subject in political science. Important contributions are Alexis De Tocqueville, Det gamle regime og revolusjonen (Oslo: Aschehoug, 1988 (1856)); Harold D. Lasswell, Power and Society (New Haven: Yale University Press, 1950); Carl Joachim Friedrich, Man and His Gooernment (New York: McGraw-Hill, 1963); Rodney Barker, Political Legitimacy and the State (Oxford: Clarendon Press, 1990); Henry Tudor, Political Myth (London: Pall Mall, 1972); David Beetham, The Legitimation of Power (Basingstoke: Macmillan, 1991);
James S. Fishkin, Tyranny and Legitimacy, A Critique of Political Theories (Baltimore: The Johns Hopkins University Press, 1979); T. H. Rigby and Ferenc Feher, Political Legitimation in Communist States (London: Macmillan, 1982).

3 These distinctions are used by Vladislav M. Zubok in his article "The Collapse of the Soviet Union: Leadership, Elites, and Legitimacy", in Geir Lundestad ed., The Fall of Great Powers (Oslo: Scandinavian University Press/Oxford University Press, 1994).

4 Cf. Edward Friedman, "Reconstructing China's National Identity: A Southern Alternative to Mao-Era 
(Beijing: Foreign Language Press, 1981).

6 Tbid.

7 Discussed in François Furet's great essay, The Lost Illusion: An Essay on the Idea of Communism in the Twentieth Century (Oslo: Aschehoug, 1996).

8 Deng Xiaoping, Selected Works 19751982 (Beijing: Foreign Language Press, 1984), p. 395.

9 Deng Xiaoping, "On Reforming the Party and State Leadership", (August 18, 1980), in Harold C. Hinton ed., The People's Republic of China 1979-1984, A Documentary Survey, vol. 1 (Wilmington, Del.: Scholarly Resources, 1986). The speech which was applauded in the politburo was published three years later, and republished in 1987.

10 See Stanley Rosen, "The Rise (and Fall) of Public Opinion in Post-Mao China", in Richard Baum, ed., Reform and Reaction in Post-Mao China; The Road to Tiananmen (New York and London: Routledge, 1991). See also Beijing Review, June, 3-9 1996: "Public opinion polls are a reliable means of understanding public psychology, with results providing reference values for policy-makers. . . . A government decision can hardly be instituted smoothly when a poll indicates 75 percent of residents express opposition. . . Public views . . . are becoming the basis for decision-making on the part of an ever-increasing number of Chinese."

11 The survey was carried out in cooperation with the Department of Comparative Politics at the University of Bergen and a survey research institute in Beijing. A suggestion is that the urban population has experienced several aspects of the reform policies since 1978 , and may be more touched by the reforms in their daily life than the rest of the population. In addition to the mass survey, we did in-depth interviews in Beijing, mainly to check the validity of the survey.

12 Pearson's $r$ : $r=0$ means no correlation, $r=1$ means total positive correspondence. Related to these kind of data, $r=0.59$ means a rather high positive correlation.

13 This thesis is in line with J. C. Davies's theory of relative deprivation: "Revolutions are most likely to occur when a prolonged period of objective economic and social development is followed by a short period of sharp reversal. ... The actual state of socioeconomic development is less significant than the expectation that past progress, now blocked, can and must continue in the future." J. C. Davies "Toward a Theory of Revolution", American Sociological Review, Vol. 27 (1962), p. 5.

14 Guanxi refers to the connection a person establishes in building personal networks.

15 The term "democratic parties" refers in China to the eight other parties apart from the Communist Party which take part in the Chinese People's Political Consultative Conference. These parties are remnants from the time before 1949 and play a symbolic role in politics.

16 The concepts are developed by Fei Xiaotong, From the Soil - the Foundations of Chinese Society (Berkeley: University of California Press, 1992).

17 This is a support to Edward Friedman's thesis in National Identity and Democratic Prospects in Socialist China (Armonk, NY: M.E. Sharpe, 1995), p. 312: "Chinese fear that a failed democratic thrust could hasten national disintegration and civil war. In fact, it could. The rulers aim their propaganda of dictatorial harmony at this widespread cacophony of anxiety. The dictators in China survive be- 
cause people prefer a known 'bad' to an unknown potential disaster of bloody chaos that, in politics, is the worst of the worst."

18 Far Eastern Economic Review, 7 March, 1996: "After 17 years of giving priority to economic development, China's leaders are calling for a return to ageold concepts of morality and selfsacrifice. The Chinese Communist Party says the ideological theme of the plenary meeting of its Central Committee will be 'spiritual civilization'. In the past China launched cam- paigns against 'spiritual pollution' from the West. Already, new school textbooks stress traditional Chinese ethics. China is likely to emphasize such virtues as thrift, selflessness, loyalty and patriotism."

19 Adam Przeworski, "Some Problems in the Study of Transition to Democracy", in Guillermo O'Donnell, Philippe C. Schmitter, and Laurence Whitehead, Transitions from Authoritarian Rule. Comparative Perspectives (Baltimore: The Johns Hopkins University Press, 1986), p. 52. 